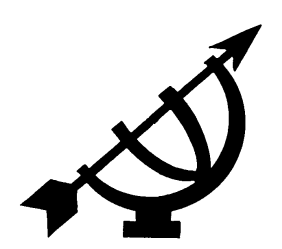

\title{
Die rol van 'n mentor vir seuns tydens die oorgangsfase van die laat-middelkinderjare na adolessensie
}

\author{
J.P.D. Steytler \& H. Strydom
}

Skool vir Psigososiale Gedragswetenskappe: Maatskaplike Werk

Potchefstroomkampus

Noordwes-Universiteit

POTCHEFSTROOM

E- pos: jsteytler@gmail.com

herman.strydom@nwu.ac.za

\begin{abstract}
The role of a mentor for boys during their transition phase from late middle childhood to adolescence

Boys in their late middle childhood experience far-reaching changes in their lives. Reaching puberty and experiencing the transition from childhood to adolescence causes immense stress and tension. The intensity of the relationship between father and son decreases many times, while involvement with the peer group increases. This article focuses on the experiences of the boys in their late middle childhood regarding their biological father and the influence of the family hierarchy. As alternative father figure, the focus falls on a mentor. The longing for a mentor and the expectations of the boys in their late middle childhood in this regard are explored in this article.
\end{abstract}

\section{Opsomming}

Die rol van 'n mentor vir seuns tydens die oorgangsfase van die laat-middelkinderjare na adolessensie

Seuns in hulle laat-middelkinderjare beleef verreikende veranderings in hulle lewens. Die bereiking van puberteit en die oorskakeling van kinderjare na adolessensie veroorsaak groot spanning en wrywing. Die intensiteit van die verhouding tussen pa en seun neem dikwels af terwyl die betrokkenheid in portuurgroepe weer toeneem. Hierdie artikel fokus op die seun in sy laat-middelkinderjare se belewing van sy biologiese pa en die invloed van die gesinsrangorde. As alternatiewe vaderfiguur 
word die klem op 'n mentor gelê. Die behoefte aan 'n mentor en die verwagtings wat die seun in sy laat-middelkinderjare het rakende die mentor, word ondersoek.

\section{Inleiding}

Die doel van hierdie artikel is om vas te stel of daar 'n behoefte aan 'n mentor by seuns in die platteland sowel as in die verre platteland is tydens die seun se oorgangsfase van die middelkinderjare na adolessensie. Aspekte wat in berekening gehou is en wat in die resultate uiteengesit word, is die gesinsrangorde en die teenwoordigheid en/of die mate van betrokkenheid van die biologiese pa. Data is ook ingesamel rakende die behoeftes wat die deelnemers het ten opsigte van ' $n$ mentor en watter verwagtings hulle van sodanige mentorverhouding koester.

Om 'n profiel van die deelnemers saam te stel, is daar nie alleen op die getal deelnemers gefokus nie, maar ook op die getal seuns in die huisgesin en die rangorde van die gesinslede. Geen onderskeid is getref tussen koshuisinwoners en nie-koshuisinwoners nie. Die studie fokus op individuele deelnemers se behoefte aan 'n mentor en mentorverhouding. Vir 'n meer holistiese perspektief op die onderwerp is die navorsingsopname in twee geografiese streke in Suid-Afrika gemaak. Die eerste streek, die platteland, is in die munisipale gebied van Potchefstroom in die Noordwes-provinsie met 'n populasiegroep van 128352 mense, waarvan 29104 wit is (South Africa, 2004:939). Die tweede streek, die verre platteland, is die gebiede van Jacobsdal en Luckhoff in die munisipale gebied van Letsemeng, met 'n populasie van 42 981, waarvan 4174 wit is, Douglas in die munisipale gebied van Siyancuma in die Suid-Vrystaat met 'n populasie van 35809 , waarvan 3651 wit is en Hopetown in die Noord-Kaap in die munisipale gebied van Thembelihle met 'n populasie van 19 986, waarvan 1939 wit is (South Africa, 2004:495, 848, 851).

\section{Agtergrond/Probleemstelling}

Kinders in hulle laat-middelkinderjare ondergaan daagliks verandering. Hierdie verandering kan fisies, psigies, emosioneel, kognitief of geestelik wees en is nie noodwendig toe te skryf aan die maatskaplike omgewing waarin hulle woon nie, maar ook aan biologiese veranderings, soos dié gekoppel aan puberteit.

Seuns met 'n afwesige pa kan 'n pa-honger beleef (Erickson, 1996: 39; Freeks, 2004:23) - 'n hunkering na 'n manspersoon met wie 
hulle kan identifiseer; 'n ondersteuningsbasis. Vygotsky se sosiale leerteorie verduidelik dat 'n mens nuwe vaardighede aanleer deur interaksies met mense. Hierdie deelnemers, in hulle oorgangsfase, word nie hiervan uitgesluit nie. Weens die feit dat hierdie seuns hulle tweede vormingsperiode betree (Gurian, 1998:84), is die voldoening aan genoemde behoefte van kardinale belang. 'n Plaasvervangende vaderfiguur of mentor, kan help vorm aan hulle identiteit en bou aan hulle beeld van wat 'n man behoort te wees en wat sy rol is.

In hierdie afdeling word 'n uiteensetting gegee van die kwantitatiewe en kwalitatiewe data wat met die empiriese ondersoek, tesame met 'n literatuurstudie ingesamel is. Die data word grafies en in tabelvorm weergegee. Direkte aanhalings van die deelnemersresponse en hulle grafiese voorstellings word ook aangewend en weergegee. Die doelwitte van hierdie artikel is om:

- die deelnemers se belewing van hulle biologiese pa weer te gee; en

- die deelnemers se behoefte aan en verwagtings van 'n mentorverhouding te identifiseer.

\section{Navorsingsmetodologie}

'n Moderne navorsingsproses bevat enkele basiese eienskappe, naamlik dat dit met ' $n$ probleem begin en met 'n gevolgtrekking afsluit. Die proses is op waarneembare feite (data) gebaseer. Die argumentasielyn is logies en georden en gaan gepaard met 'n redelike en toepaslike hipotese. Die proses bevestig of verwerp die hipotese slegs op grond van feite. Die navorsing sluit af met 'n gevolgtrekking wat slegs op data gegrond word wat uit die ondersoek bekom is. Die gevolgtrekking verantwoord die probleem wat geïdentifiseer is (Fouché \& Delport, 2005:72).

'n Opnameprosedure as kwantitatiewe benadering is met $85(\mathrm{~N}=85)$ seuns in die platteland en met $65(\mathrm{~N}=65)$ in die verre platteland onderneem. Weens die feit dat die kwantitatiewe data van die platteland en dié van die verre platteland nie verskil nie, word dit saamgevoeg en as 'n geheel gebruik. Vir verdere doeleindes word daarna verwys as kwantitatiewe data. Die totale getal deelnemers vir die kwantitatiewe ondersoek is dus $150(\mathrm{~N}=85+65=150)$. Die kwantitatiewe ondersoek is 'n statistiese analise wat gebruikmaak van numeriese vergelykings (Barker, 2003:354). Vraelyste wat op die basis van 'n Likert-skaal funksioneer (Neuman, 2003:197) is by die deelnemende skole en koshuise uitgedeel, waartydens die 
deelnemers dit dadelik ingevul het. Sommige deelnemers het nie die vraelyste volledig ingevul nie, en hulle data is verwerp ten einde geldigheid en betroubaarheid te verhoog.

Vir die kwalitatiewe empiriese ondersoek is $40(N=40)$ deelnemers uit die kwantitatiewe ondersoek deur middel van 'n nie-waarskynlikheid-seleksietipe, kwotasteekproef geïdentifiseer (Strydom, 2005: 202). Twintig deelnemers is uit die platteland afkomstig en twintig uit die verre platteland $(\mathrm{N}=40)$. Die data is verkry deurdat die deelnemers sowel groep- as self-geadministreerde vraelyste ingevul het (Delport, 2005:168-170). Onderhoude is voorts met die deelnemers gevoer om die betroubaarste en mees doelgerigte data te bekom.

'n Literatuurstudie is onderneem om die data te ondersteun of te verwerp, of nuwe insigte rakende die ondersoek te verkry. Met die kwalitatiewe en kwantitatiewe empiriese ondersoek, tesame met die literatuurstudie, is triangulering bewerkstellig om die betroubaarheid van die data te verhoog. Triangulering is die toepassing van verskillende metodes om ooreenstemmende bevindings te toets (Babbie, 2004:113).

Kinders verskil van kultuur tot kultuur en word verskillend in ooreenstemming met hulle kultuur en geloof opgevoed (Bernardes, 1997:108; Zastrow \& Kirst-Ashman, 2004:220). Bernardes (1997: 108) verwoord dit duidelik:

It is vital, at the outset, to clarify the point that the very idea of childhood is located in history and culture; different cultures have treated children rather differently in various historical periods.

Soos daar groot verskille tussen kulture voorkom, bestaan daar ook binne elke kultuur verskille tussen seuns en dogters. Om die studie op een groep te kan konsentreer, fokus hierdie studie op die Afrikaanssprekende wit seun.

\section{Profiel van die deelnemers}

By die studie is $150(\mathrm{~N}=150)$ deelnemers betrek (vgl. Tabel 1). Daarvan is $49(32,7 \%) 12$ jaar oud, $51(34,0 \%) 13$ jaar en 50 $(33,3 \%) 14$ jaar oud. Uit hierdie deelnemers is 40 vir die kwalitatiewe empiriese ondersoek geselekteer. Die deelnemers vanuit die platteland woon almal in by die gesin, terwyl sommige van die deelnemers in die verre platteland in die week in die koshuis woon. Daar is nie 'n verskil tussen die dorpskinders en koshuisinwoners se resultate nie en dit word dus as 'n geheel saamgevoeg. 
Tabel 1: Uiteensetting van die deelnemers

\begin{tabular}{|c|c|c|c|c|c|c|}
\hline \multirow{2}{*}{ Ouderdom } & \multicolumn{2}{|c|}{ Platteland } & \multicolumn{2}{|c|}{ Verre platteland } & \multicolumn{2}{|c|}{ Gesamentlik } \\
\hline & 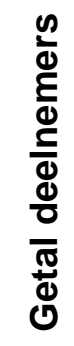 & $\begin{array}{l}\frac{0}{9} \\
\frac{\pi}{2} \\
\frac{0}{0} \\
\frac{\omega}{0} \\
0 \\
0\end{array}$ & 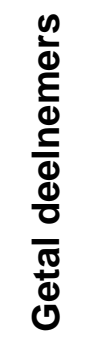 & $\begin{array}{l}\frac{0}{9} \\
\stackrel{\pi}{0} \\
\Phi \\
\frac{\omega}{0} \\
0\end{array}$ & 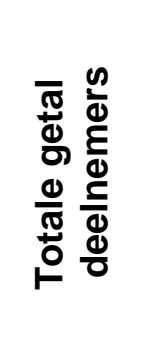 & $\begin{array}{l}\frac{0}{9} \\
\frac{\pi}{2} \\
\frac{0}{d} \\
\frac{\omega}{0} \\
\square\end{array}$ \\
\hline 12 Jaar & 25 & 16,7 & 24 & 16,0 & 49 & 32,7 \\
\hline 13 Jaar & 33 & 22,0 & 18 & 12,0 & 51 & 34,0 \\
\hline 14 Jaar & 27 & 18,0 & 23 & 15,3 & 50 & 33,3 \\
\hline Totaal & 85 & 56,7 & 65 & 43,3 & $\mathrm{~N}=150$ & 100,0 \\
\hline
\end{tabular}

$(\mathrm{N}=150)$

Die aanvang van adolessensie word meestal gekenmerk deur die bereiking van puberteit - die tydperk van biologiese groei om vir voortplanting gereed te word (Barker, 2003:8,349; Cole \& Cole, 2001:610; Pruitt, 1999:5). Die bereiking van puberteit verskil egter van seun tot seun en kan dus nie aan 'n ouderdom gekoppel word nie. Dit is egter nie altyd van toepassing nie, weens die feit dat seuns nog tot op die ouderdom van 15 jaar puberteit kan bereik en dan reeds 'n adolessent is (Gurian, 1998:86; Papalia et al., 2006: 414). Volgens hierdie kriteria van 'n adolessent val sommige van die deelnemers aan hierdie studie binne die groepering van adolessent, alhoewel hulle moontlik nog 12 jaar oud is en eintlik nog in die groepering van die laat-middelkinderjare pas. Om hierdie verwarring oor laat-middelkinderjare en adolessensie te oorbrug, word na die deelnemers verwys as seuns in hulle laat-middelkinderjare wat in die oorgangsfase van die middelkinderjare na adolessensie verkeer.

Hierdie oorgangslewensfase is vir sommige seuns 'n uiters moeilike tydperk as gevolg van die talle veranderings wat hulle ondergaan. Aspekte wat betrek is by die ondersoek is die deelnemers se rangorde in die gesin, die deelnemers se belewing van hulle biologiese pa se betrokkenheid by hulle asook hulle behoefte aan 'n mentor.

\subsection{Gesinsrangorde}

Gesinsrangorde dui op die ouderdomsvolgorde van die gesinslede. Vir hierdie doeleindes word na die biologies pa verwys as die hoof 
van die gesin. Hy staan dus eerste in die gesinsrangorde, gevolg deur die biologiese ma en dan die kinders - ouderdomsgewys.

Louw et al. (1998:357) is van mening dat die aantal kinders in die gesin sowel as die rangorde van die kind in die gesin bepaalde implikasies vir sy sosiale en persoonlikheidsontwikkeling inhou. Van die $150(\mathrm{~N}=150)$ deelnemers aan die studie was $16(10,7 \%)$ enkelkinders, $54(36,0 \%)$ een van twee kinders en 80 (53,3\%) een van drie of meer kinders in die gesin. Die meerderheid deelnemers was die derde of latere kind, gevolg deur die tweede kind en die enkelkinders was in die minderheid.

Onder hierdie $150(\mathrm{~N}=150)$ deelnemers was $67(44,7 \%)$ die enigste seun in die gesin, $56(37,3 \%)$ twee seuns in die gesin en $27(18,0 \%)$ drie of meer seuns in die gesin. In teenstelling met die statistiek ten opsigte van die getal kinders in die gesin, was die enigste seun die sterkste in die groep verteenwoordig, gevolg deur twee seuns en laastens deur drie of meer seuns in die gesin.

Van die $150(\mathrm{~N}=150)$ deelnemers, was $100(66,7 \%)$ die oudste of enigste seun in die gesin, $36(24,0 \%)$ die tweede seun en $14(9,3 \%)$ die derde of latere seun in die gesin. Hierdie besonder hoë deelname deur die oudste seun, persentasiegewys, word deur die ondersoek van Louw et al. (1998:357-358) bevestig, deurdat hulle daarop wys dat die oudste kind geneig is om meer selfvertroue te openbaar, meer verantwoordelik op te tree en om oor volwasse modelle te beskik. Die deelnemers wat genader is om aan die ondersoek deel te neem, is nie vooraf op grond van gesinsrangorde bepaal nie, maar geïdentifiseer aan die hand van 'n nie-waarskynlikheid-seleksietipe, naamlik 'n kwotasteekproef (Strydom, 2005:202).

\subsection{Biologiese pa}

Bernardes (1997:170) meen dat in 'n Westerse samelewing vaderskap slegs ' $n$ status is, vergeleke met moederskap wat 'n aktiewe rol is. Hierdie stelling plaas die pa, die hoof van die gesin, op die agtergrond, en hou 'n negatiewe beeld van die man voor. ' $\mathrm{Pa}$ is, of behoort, die natuurlike rolmodel van sy seun te wees, wat op soek is na iemand met wie hy kan identifiseer (Erickson, 1996:38; Havenga, 2002:77; Warren, 1998:102). Albei ouers, en nie slegs die ma nie, is vir die primêre versorging van die kind verantwoordelik.

Verskeie outeurs soos Freeks (2004:3), Gurian (1998:50) en Havenga (2002:32) is van mening dat seuns wat met 'n afwesige pa 
grootword, geneig is om maatskaplik swakker te funksioneer. Psigososiale stressors soos ekonomiese druk, huwelikskonflik, depressie en enkelouerskap bring mee dat ouers killer teenoor hulle kinders optree. Hierdie stressors beïnvloed die ouers se interaksie met hul kinders (O'Connor et al., 2006:498). Volgens hierdie outeurs plaas dit die deelnemers met 'n afwesige pa in omstandighede wat tot swakker lewensgehalte kan lei.

Indien die verhouding met die biologiese pa na 'n egskeiding nie in stand gehou word nie, kan dit onbevredigde behoeftes by die seun laat (Jansen van Rensburg, 2004:31). Dit wat die seun rakende sy pa beleef, word aan die seun se persepsie van die begrip pa gekoppel. Hierdie patrone kan óf negatief óf positief wees, en die seun gaan aanvanklik hierdie patrone met sy eie kinders herhaal (Hendricks \& Hendricks, 1995:27). O'Connor et al. (2006:504) het deur navorsing bevind dat meer konflik in die pa-seunverhouding voorkom as in 'n pa-dogterverhouding. Hierdie konflik tussen pa en seun moet gekanaliseer word sodat die seun uiting kan gee aan sy emosies. 'n Mentor, wat nie deel van die gesinsopset uitmaak nie, kan hier die nodige ondersteuning bied.

Van die 150 (N=150) deelnemers woon 117 (78,0\%) nog by hulle biologiese pa's. Dit sluit geskeide gesinne in waar die biologiese pa toesig en beheer oor die kinders verkry het. Van die 33 biologiese pa's wat nie meer by hulle seuns woon nie, is $8(5,3 \%)$ oorlede, 22 $(14,7 \%)$ geskei waartydens die ma toesig en beheer oor die kinders verkry het, $1(0,7 \%)$ is onbekend en $2(1,3 \%)$ is om ander redes (byvoorbeeld weens die uitdiening van gevangenisstraf) nie meer by die gesin woonagtig nie. Die meerderheid deelnemers kom dus uit gesinne waarvan die biologiese pa nog by die gesin woon.

\subsubsection{Betrokkenheid van die biologiese pa}

Posel en Devey (2006:48) noem dat 51,1\% van alle pa's in SuidAfrika in 1998 in die lewe van hulle kinders afwesig was. Die data wat ingesamel is, is in twee afdelings onderverdeel, naamlik die betrokkenheid van die biologiese pa wat by die gesin woon en die betrokkenheid van die biologiese pa wat nie by die gesin woon nie. Pruitt (1999:115) en Sanders (2004:1) is van mening dat kinders meer tyd by broers en susters deurbring as by enige ander persoon (die minste by die pa). Seuns het egter 'n behoefte daaraan dat hulle biologiese pa's ' $n$ rol in hulle lewe moet vervul. Die bevindings word in Tabel 2 en Tabel 3 uiteengesit. Tabel 3 fokus slegs op die biologiese pa's wat nie by die gesin woon nie as gevolg van egskeiding. 
Tabel 2 en Tabel 3 toon dat 86 (73,5\%) van die deelnemers wie se biologiese pa's nog by die gesin woon, hulle pa as aktief betrokke by alles beleef teenoor die $7(31,8 \%)$ wie se biologiese pa's geskei is en nie meer in dieselfde huis as die deelnemer woon nie. Vyf $(22,7 \%)$ van die deelnemers uit geskeide gesinne beleef hulle biologiese pa as onderskeidelik by niks en by min dinge in hulle lewens betrokke in vergelyking met die $1(0,9 \%)$ biologiese pa wat by die gesin woon. Volgens hierdie data is dit duidelik dat die deelnemers die biologiese pa's wat by die gesin woon, meer aktief beleef as wat die geval is waar die biologiese pa's as gevolg van egskeiding nie meer in die huis woon nie.

Persentasiegewys is daar meer pa's by die lewens van hulle seuns betrokke as wat Posel en Davey (2006:48) aandui. Genoemde navorsing van Posel en Davey is egter nie net op die wit Afrikaanssprekende seun gedoen nie, en dit verklaar moontlik waarom die getalle aansienlik verskil. 'n Opvallende aspek van die deelnemers wie se biologiese pa's nie meer by die gesin woon nie, is dat die hoogste syfer van $7(31,8 \%)$ onder die betrokke deelnemers uit die geskeide gesinne, die pa's tog as betrokke by alles in hulle lewens ervaar. In die 12-jaar ouderdomsgroep, ongeag of die biologiese pa's nog by die gesin woon of nie, beleef die deelnemers hulle biologiese pa's die minste betrokke by alles in hulle lewens vergeleke met die ander ouderdomsgroepe. Laasgenoemde deelnemers beleef hulle biologiese pa's eerder gemiddeld tot en met geensins betrokke nie (kyk Tabel 3).

\section{Tabel 2: Betrokkenheid van biologiese pa wat by die gesin woon}

\begin{tabular}{|c|c|c|c|c|c|c|c|c|c|c|}
\hline \multirow[b]{2}{*}{ 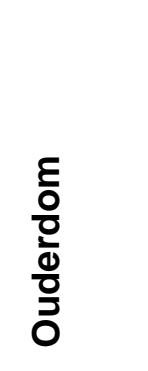 } & \multicolumn{2}{|c|}{ By alles } & \multicolumn{2}{|c|}{$\begin{array}{c}\text { By 'n paar } \\
\text { dinge }\end{array}$} & \multicolumn{2}{|c|}{ Gemiddeld } & \multicolumn{2}{|c|}{$\begin{array}{c}\text { By min } \\
\text { dinge }\end{array}$} & \multicolumn{2}{|c|}{$\begin{array}{l}\text { By niks } \\
\text { nie }\end{array}$} \\
\hline & $\begin{array}{l}\frac{0}{\omega} \\
\frac{c}{d} \\
\frac{x}{d} \\
\frac{d}{L}\end{array}$ & 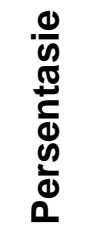 & 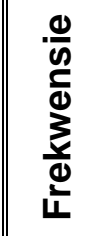 & 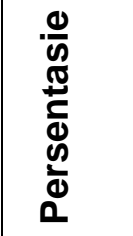 & $\begin{array}{l}\frac{0}{N} \\
\frac{c}{d} \\
\frac{d}{d} \\
\frac{d}{L}\end{array}$ & 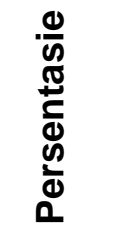 & 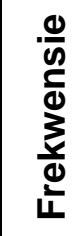 & 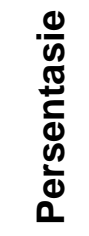 & 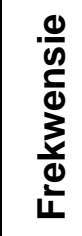 & 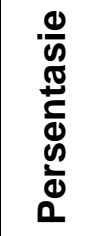 \\
\hline 12 Jaar & 24 & 20,5 & 7 & 6,0 & 3 & 2,6 & 1 & 0,9 & 1 & 0,9 \\
\hline 13 Jaar & 32 & 27,4 & 8 & 6,9 & 3 & 2,6 & 0 & - & 0 & - \\
\hline 14 Jaar & 30 & 25,6 & 6 & 5,1 & 2 & 1,7 & 0 & - & 0 & - \\
\hline Totaal & 86 & 73,5 & 21 & 17,9 & 8 & 6,9 & 1 & 0,9 & 1 & 0,9 \\
\hline
\end{tabular}

$(\mathrm{N}=117)$ 
Kotze (2004:54) het navorsing gedoen oor die graad 7-leerling en het bevind dat $72 \%$ van die deelnemers aangedui het dat kommunikasieprobleme tussen die ouer en die kind voorkom. Hierdie kommunikasieprobleem in die ouer-kindverhouding, die moontlikheid van 'n afwesige pa en die behoefte by die seun aan 'n vaderfiguur maak dit noodsaaklik dat die seun 'n mentor in sy lewe moet hê - 'n manspersoon wat hom help, hom ondersteun, lei en bemagtig en die beste in die seun na vore bring. Voorsiening in die basiese behoeftes van die seun lê op die eerste vlak van Maslow se behoeftehiërargie (Larson, 2006:681; Rathus, 2005:367). Hierdeur word die klem op die versorging en betrokkenheid van die biologiese pa beklemtoon. Ongelukkig heers daar wêreldwyd kommer oor die feit dat die betrokkenheid van biologiese pa's afneem en dat hulle meer afwesig raak in die lewens van hulle seuns (Freeks, 2004:2).

Tabel 3: Betrokkenheid van die geskeide biologiese pa wat nie by die gesin woon nie

\begin{tabular}{|c|c|c|c|c|c|c|c|c|c|c|}
\hline \multirow[b]{2}{*}{$\begin{array}{l}\varepsilon \\
\frac{\Xi}{0} \\
\frac{0}{0} \\
\frac{0}{\partial} \\
0\end{array}$} & \multicolumn{2}{|c|}{ By alles } & \multicolumn{2}{|c|}{$\begin{array}{l}\text { By 'n paar } \\
\text { dinge }\end{array}$} & \multicolumn{2}{|c|}{ Gemiddeld } & \multicolumn{2}{|c|}{$\begin{array}{c}\text { By min } \\
\text { dinge }\end{array}$} & \multicolumn{2}{|c|}{$\begin{array}{c}\text { By niks } \\
\text { nie }\end{array}$} \\
\hline & 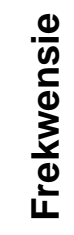 & 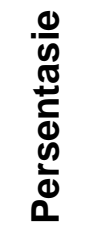 & 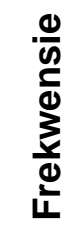 & 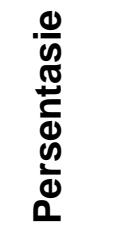 & 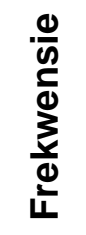 & $\begin{array}{l}\frac{0}{0} \\
\frac{\pi}{0} \\
\frac{0}{0} \\
\frac{0}{0} \\
0\end{array}$ & $\begin{array}{l}\frac{0}{n} \\
\frac{c}{d} \\
\frac{\mathbf{x}}{d} \\
\frac{1}{4}\end{array}$ & 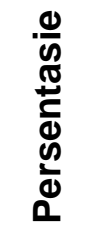 & 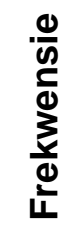 & $\begin{array}{l}\frac{0}{0} \\
\frac{\pi}{0} \\
\frac{0}{0} \\
\frac{\omega}{0} \\
\square \\
0\end{array}$ \\
\hline 12 Jaar & 0 & - & 1 & 4,5 & 2 & 9,1 & 3 & 13,6 & 4 & 18,2 \\
\hline 13 Jaar & 3 & 13,6 & 2 & 9,1 & 0 & - & 0 & - & 0 & - \\
\hline 14 Jaar & 4 & 18,2 & 0 & - & 0 & - & 2 & 9,1 & 1 & 4,5 \\
\hline Totaal & 7 & 31,8 & 3 & 13,6 & 2 & 9,1 & 5 & 22,7 & 5 & 22,7 \\
\hline
\end{tabular}

$(\mathrm{N}=22)$

\section{Die mentorverhouding}

Who are the people who have helped to make you who you are today? I'm referring to the people who have marked you, who have made a significant impact, a lasting impression on your life. (Hendricks \& Hendricks, 1995:13.)

\subsection{Die mentor as alternatief vir die afwesige pa}

Seuns het 'n vaderfiguur, 'n mentor, iemand wat in hom glo, hom ondersteun en bystaan, nodig. Hierdie persoon dien as voorbeeld, rolmodel en opvoeder vir die jonger persoon - voorsien hom van kennis, advies, berading, ondersteuning en geleenthede (Eldredge, 
2006:4-5; Encarta Dictionary, 2006; Hendricks \& Hendricks, 1995: 28-29). Ndabazandile (2006:14) beskryf 'n mentor as 'n betroubare berader of rigtinggewer - iemand wat invloedryk is, ondervinding het, ' $n$ persoonlike verhouding met die seun aanknoop en hom help om sy doelwitte te bereik. Al is die biologiese pa die natuurlike mentor van die seun, beteken dit nie dat hy noodwendig as mentor vir sy seun optree nie. Ouer broers kan ook as mentors vir jonger broers optree. Eldredge (2006:5) stel dit soos volg: "A boy learns who he is and what he's made of from a man (or a company of men.) This can't be learned in any other place. It can't be learned from other boys, and it can't be learned from the world of women."

Mans verstaan seuns en die uitdagings wat hulle in die gesig staar omdat hulle dit self moes bemeester. Seuns van dieselfde portuurgroep ervaar dieselfde uitdagings en kan dit nie vanuit 'n volwasse oogpunt beoordeel nie, daarom is dit belangrik dat volwasse mans seuns deur hierdie moeilike situasies moet lei. Ouer broers kan 'n hegte band met jonger broers smee, en onderlinge verhoudings tussen broers word hegter en meer ondersteunend namate hulle vroeë volwassenheid bereik (Buhrmester \& Furman, 1990:13871388; Pruitt, 1999:115).

\subsection{Die behoefte aan 'n mentor}

Tabel 4: Behoefte aan 'n mentor volgens gesinsrangorde

\begin{tabular}{|c|c|c|c|c|c|c|c|c|c|c|}
\hline & \multicolumn{2}{|c|}{ Oudste seun } & \multicolumn{2}{|c|}{ Tweede seun } & \multicolumn{2}{|c|}{ Derde seun } & \multicolumn{2}{|c|}{ Vierde seun } & \multicolumn{2}{|c|}{ Vyfde seun } \\
\hline & $\begin{array}{l}\frac{0}{9} \\
\frac{c}{d} \\
\frac{1}{d} \\
\frac{1}{\square}\end{array}$ & 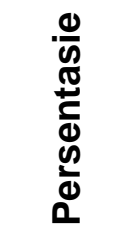 & 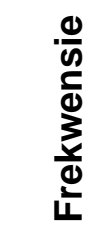 & 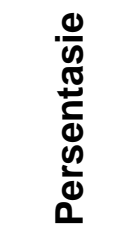 & 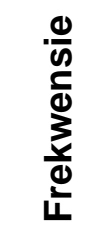 & 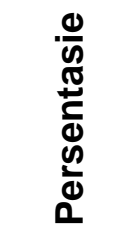 & 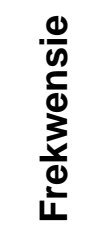 & 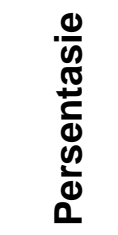 & $\begin{array}{l}\frac{0}{N} \\
\frac{c}{d} \\
\frac{d}{2} \\
\frac{d}{d} \\
\frac{0}{4}\end{array}$ & 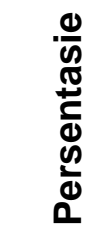 \\
\hline $\begin{array}{l}\text { Behoefte } \\
\text { aan 'n } \\
\text { mentor }\end{array}$ & 75 & 75,0 & 21 & 58,3 & 10 & 83,3 & 1 & 100,0 & 1 & 100,0 \\
\hline $\begin{array}{l}\text { Geen } \\
\text { behoefte } \\
\text { aan 'n } \\
\text { mentor } \\
\text { nie }\end{array}$ & 25 & 25,0 & 15 & 41,7 & 2 & 16,7 & - & - & - & - \\
\hline Totaal & $\mathrm{N}=100$ & 100,0 & $\mathrm{~N}=36$ & 100,0 & $\mathrm{~N}=12$ & 100,0 & $\mathrm{~N}=1$ & 100,0 & $\mathrm{~N}=1$ & 100,0 \\
\hline
\end{tabular}

Uit die $150(\mathrm{~N}=150)$ deelnemers het $108(72 \%)$ aangedui dat hulle 'n behoefte het aan 'n mentor, terwyl 42 (28\%) die teendeel aangedui het. In Tabel 4 word 'n uiteensetting gegee van die behoefte aan 'n 
mentor by die verskillende deelnemers. Die uiteensetting is ooreenkomstig gesinsrangorde uiteengesit.

Volgens Tabel 4 het 75 (75\%) van die deelnemers wat die oudste seun in die gesin is 'n behoefte aan 'n mentor, teenoor 21 (58,3\%) van die deelnemers wat die tweede seun in die gesin is. Die tweede seun in die gesin, kan die oudste seun as 'n mentor beleef en kan daarom ' $n$ laer behoefte toon aan ' $n$ buitestander as mentor. Die deelnemers wat die derde seun of jonger in die gesin is, toon die sterkste behoefte aan 'n mentor - tussen 83,3\% en 100\%. Daar moet egter in gedagte gehou word dat die hoeveelheid deelnemers wat die derde of latere seun is, gering was. Hierdie persoon wat die deelnemers as ' $n$ mentor beleef, is nie noodwendig die biologiese pa nie, maar in sommige gevalle 'n ouer broer, 'n ouer vriend of 'n buitestander. Buhrmester en Furman (1990:1396) verduidelik dat jonger kinders na ouer kinders opsien en waarde heg aan die interaksie. Eldredge (2006:5) en Farrar (2006:13) is van mening dat 'n vrou nie 'n mentor vir 'n seun kan wees nie. Laasgenoemde outeur spreek hom soos volg uit:

But if you let your wife become the primary mentor of your sons, one of two things will end up happening. They will grow up to be feminized men, or they will grow up to be angry men.

Net soos slegs 'n man 'n mentor vir 'n seun kan wees, so kan slegs 'n vrou 'n mentor vir 'n dogter wees. Dit word daaraan toegeskryf dat net dieselfde geslag regtig op alle vlakke met dieselfde geslag kan vereenselwig.

Die onderhawige studie het bewys dat die tweede oudste seun in die gesin die minste behoefte aan 'n mentor het, naamlik 15 (41\%) van die groep. Hierdie kinders beleef egter soms dat hulle nooit 'n unieke verhouding met hulle ouers het soos die oudste kind nie, en emosioneel verwerp voel (Louw et al., 1998:357-358). Daar word ook bevind dat hulle dikwels hegter bande met die portuurgroep smee as met hulle ouers. Dit kan 'n rede wees waarom hulle, in vergelyking met die ander seuns in die gesin, minder behoefte aan 'n mentor het. Die mentor as volwasse persoon word moontlik met die negatiewe beeld van die ouer geassosieer. Weens die feit dat die seun in sy oorgangsfase onder heelwat groepsdruk verkeer, is die kans baie sterk dat hy by die aktiwiteite van sy portuurgroep sal inskakel (Pruitt, 1999:10). Hierdie aktiwiteite is nie noodwendig gewens nie, daarom word die noodsaaklikheid van 'n mentor, wat die seun in die regte rigting kan lei, beklemtoon. 


\subsubsection{Redes vir die behoefte aan 'n mentor}

Met die kwalitatiewe empiriese ondersoek is 'n ondersoek geloods met betrekking tot die deelnemers se redes waarom hulle behoefte aan 'n mentor het. Enkele deelnemers se redes was die volgende:

- My pa is te besig om iets saam met my te doen.

- 'n Mentor is iemand wat vir my omgee.

- Die mentor kan met my speel, met my gesels en ek kan hom vertrou.

- Ek kan by hom leer en in sy voetstappe volg.

- My pa is oorlede en ek het 'n behoefte aan 'n mentor.

- Ek kan vaardighede by hom leer en dit weer aan ander oordra.

- Hy kan my beste vriend wees.

- Hy gee jou moed.

- Die mentor kan deelneem aan my avonture en my vriend wees.

Hieruit blyk dit duidelik dat die deelnemers 'n sterk emosionele behoefte het aan 'n persoon wat vir hulle omgee en hulle ondersteun. Eldredge (2001:60) verwoord die hartseer wat talle seuns beleef soos volg:

Every boy, in his journey to become a man takes an arrow in the center of his heart, in the place of his strength. Because the wound is rarely discussed and even more rarely healed, every man carries a wound. And the wound is nearly always given by his father.

Hartseer spreek uit hierdie aanhaling. Die gevolg van 'n afwesige pa, hetsy dood of emosioneel afwesig, word weerspieël in die deelnemers se response. Wat sterk na vore kom, is dat die deelnemers op soek is na iemand wat vir hulle lief is, hulle verstaan, hulle ondersteun, hulle rigting gee en aktief by hulle lewens betrokke is. Een deelnemer stel die konsep dissipelskap baie sterk voorop, naamlik om by die mentor te kan leer, om sodoende ook eendag vir ander seuns 'n mentor te kan wees. Die goue draad wat regdeur loop, is verhoudings. Die deelnemers het 'n behoefte aan 'n opregte, eerlike, intieme en persoonlike verhouding met 'n ouer manspersoon. 


\subsection{Die verwagtings wat van 'n mentorverhouding gekoester word}

Die verwagtings wat deelnemers van 'n mentorverhouding koester, word vervolgens uiteengesit. Die verwagtings verskil nie tussen die twee geografiese gebiede nie en word dus saamgevoeg. Ooreenstemmende aspekte wat herhaaldelik in die response van die deelnemers voorgekom het ten opsigte van wat hulle van 'n mentorverhouding verwag, is telkens onder 'n oorkoepelende begrip saamgegroepeer, naamlik aktiewe deelname, beskerming, luister, ondersteuning en rigtinggewing, en dan omskryf en verbatim aangehaal. Verder word ' $n$ volledige beskrywing van elke begrip gegee en die afleiding wat ten opsigte van elk gemaak is.

\subsubsection{Aktiewe deelname}

Aktief, volgens Odendaal en Gouws (2005:39), word beskryf as "bedrywig of vol energie" en deelname (Odendaal \& Gouws, 2005:146) as 'n "handeling" of die "meedoen aan iets". Dit blyk dus dat aktiewe deelname ' $n$ energieke handeling is wat tussen twee of meer persone plaasvind. Beskrywings deur die deelnemers wat onder hierdie definisie gekategoriseer is, handel oor optredes soos:

- Jou mentor vergesel jou op jou avonture.

- Ek en my mentor moet tyd bymekaar spandeer.

- 'n Mentor doen dinge saam met jou.

Die deelnemers het groot klem daarop gelê dat hulle 'n behoefte het aan 'n mentor wat aktief sal wees en dinge saam met hulle sal doen. 'n Ander beskrywing wat gepaard gaan met hierdie behoefte aan 'n aktiewe deelname saam met die mentor is tyd. Die deelnemers verlang daarna dat tyd van hoë gehalte aan hulle afgestaan moet word. Twee van die deelnemers verwys daarna dat jy en jou mentor kwalitatiewe tyd saam moet spandeer en dat die tyd wat julle saam deurbring, nie omgewens moet word nie. Die behoefte aan 'n persoonlike verhouding met iemand wat tyd van hoë gehalte met die deelnemers sal deurbring, tree sterk op die voorgrond.

\subsubsection{Beskerming}

Odendaal en Gouws (2005:86) beskryf beskerming as beveiliging. Labuschagne en Eksteen (1993:74) voeg egter hier by dat beskerming ook "voorspraak ten gunste van iemand", "steun" en "bevoordeling deur besondere maatreëls" beteken. Beskrywings van die deelnemers wat inpas by die gegewe definisie is: 
- Hy sal altyd kyk na gevare wat jou kan benadeel.

- Jou mentor moet jou laat veilig voel.

- Hy moet altyd vir jou opstaan, jou beskerm.

Die aksent val duidelik daarop dat die deelnemers teen ander persone beskerm moet word. Die mentor dien as beskerming en sekuriteit. Een van die deelnemers beskryf die erns van die beskerming komende van 'n mentor soos volg: "'n Mentor sal jou beskerm." Volgens Maslow se behoeftehiërargie lê die behoefte aan sekuriteit - wat beskerming insluit - op die tweede vlak (Edwards, 1998:423). Zastrow en Kirst-Ashman (2004:391) se komponente van die sekuriteitsvlak sluit in: sekuriteit, stabiliteit en vryheid van vrees, angs, bedreigings en chaos - "a social structure of laws and limits assists in meeting these needs".

Uit die beskrywing van die deelnemers blyk beskerming deur die mentor 'n voorvereiste in die mentorverhouding te wees.

\subsubsection{Luister}

Odendaal en Gouws (2005:683) gee drie beskrywings van die woord luister as werkwoord, naamlik: "met aandag hoor, aandag skenk aan", en "gehoorsaam". Die eerste twee beskrywings kom die meeste in die reaksies van die deelnemers na vore. Uitsprake van die deelnemers is onder andere:

- Ons kan met mekaar gesels oor ons probleme.

- Hy is altyd daar om na jou probleme en gedagtes te luister.

- Jy weet jy kan met hom praat oor enigiets.

'n Kernaspek wat uit die respons van die deelnemers na vore gekom het, is dat hulle 'n behoefte het aan 'n persoon wat na hulle kan luister en hulle verstaan - iemand met wie hulle enige onderwerp te eniger tyd kan bespreek. 'n Ander respons wat met luister gepaardgaan, is vertroue. Een van die deelnemers verwoord dit soos volg: "Nie geskok wees nie en jou geheime stil kan hou". Wat die deelnemer hiermee bedoel, is dat die mentor nie geskok moet wees oor onderwerpe en geheime wat die deelnemer met die mentor deel nie.

Die deelnemers het dit duidelik laat blyk dat die mentor moet kan luister, maar dat die kommunikasieproses wederkerig op 'n ontspan- 
ne wyse moet geskied. Die mentor en die deelnemer moet mekaar wedersyds kan vertrou.

\subsubsection{Ondersteuning}

Om ondersteunend op te tree, beteken om 'n persoon van "hulp te wees, hom te troos, te help of by te staan" (Odendaal \& Gouws, 2005:786). Beskrywings van die deelnemers wat by hierdie definisie aansluit is:

- Jou mentor help jou in swaar tye.

- Hy is baie ondersteunend, staan saam as een.

- Hy sal jou as 'n wenner sien.

- Hy is soos 'n pa vir almal.

- Hy help jou om dinge te doen wat jy nie kan doen nie.

Die deelnemers het 'n behoefte aan 'n persoon wat hulle geestelik, emosioneel en fisies kan ondersteun. Een van die deelnemers verwoord die boodskap baie duidelik: "Hy help jou om uniek te voel." Die deelnemers het ' $n$ behoefte aan 'n persoon wat hulle op alle terreine kan ondersteun, maar wat nie hulle lewens beheers nie. Aanvullend tot die ondersteuning wat die deelnemers van die mentor verlang, is dat hulle steeds uniek wil bly.

\subsubsection{Rigtinggewend}

In die figuurlike sin verwys rigtinggewing volgens Odendaal en Gouws (2005:938) na "strekking, denkwyse, gesindheid, beleid, stroming". Die deelnemers se beskrywing wat by die gegewe definisie aansluit, is:

- Hy moet jou die opsies wys oor die keuses wat jy wil maak.

- Jou mentor help jou om jou skip saam met die Here te seil.

- Jou mentor is iemand wat besluite en leiding kan neem.

- Hy moet jou leer om beter te word.

Die meerderheid deelnemers het 'n behoefte aan iemand wat kennis aan hulle kan oordra en hulle kan lei om die regte weg te bewandel. Van die deelnemers het die behoefte daaraan uitgespreek dat die mentor die opsies waaruit hulle ten opsigte van uitdagings kan kies, moet uitwys, maar die keuse aan hulle moet oorlaat. Uit die data 
blyk dit dat die deelnemers 'n behoefte het aan 'n persoon wat hulle sal help met rigting ten opsigte van hulle lewenspad.

Figuur 1: Deelnemer se uitbeelding van rigtinggewing

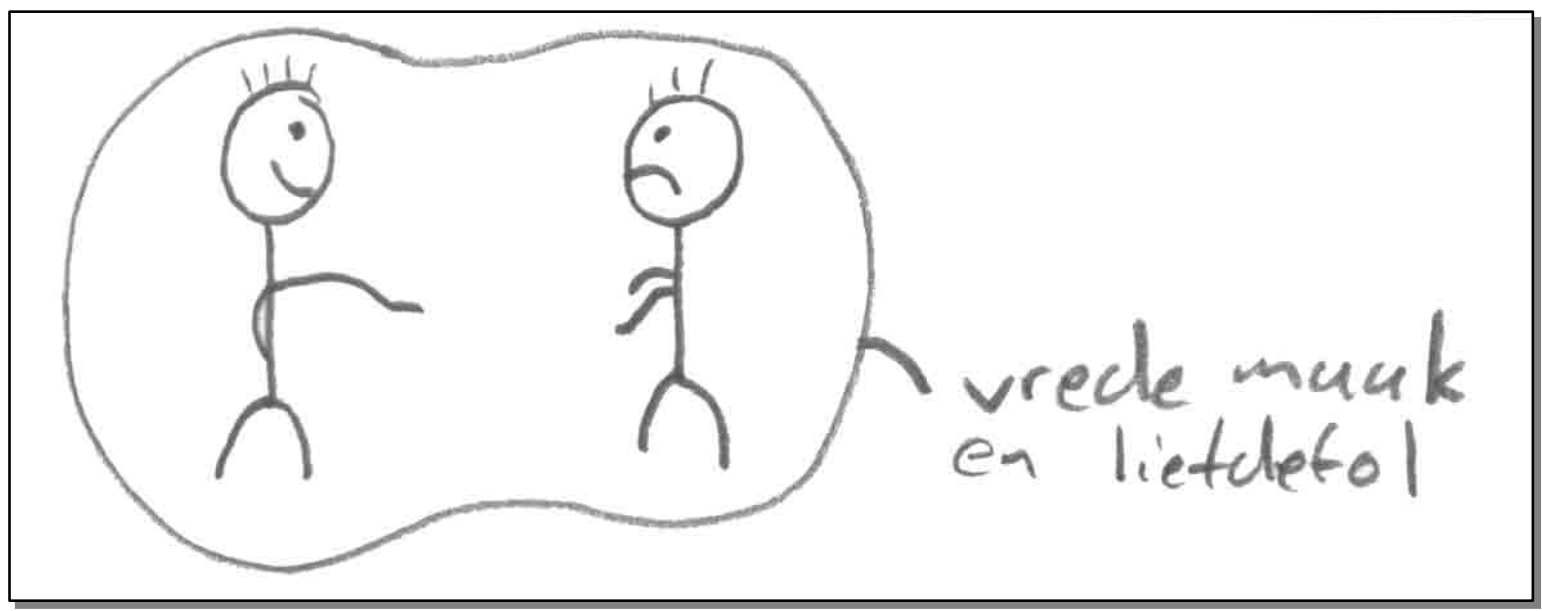

Figuur 1 is 'n grafiese uitbeelding van 'n deelnemer se behoefte aan 'n mentor. Die deelnemer illustreer hiermee dat die mentor die seun moet help om geskille op die regte wyse op te los. Dit dui dus op konflikhantering.

\subsection{Rangorde van belangrikheid van behoeftes in 'n mentorverhouding}

Die volgende rangorde is uit die data opgestel ten opsigte van eienskappe wat die deelnemers as die belangrikste in 'n mentorverhouding ag. Die deelnemers kon meer as een antwoord per vraag verstrek.

Tabel 5: Rangorde van belangrikheid ten opsigte van verwagtings wat die seuns van 'n mentorverhouding koester

\begin{tabular}{|l|l|l|l|}
\hline & Platteland (f) & Verre platteland (f) & Totaal (f) \\
\hline Aktiewe & 27 & 37 & 64 \\
deelname & 20 & 29 & 49 \\
Beskerming & 31 & 32 & 63 \\
Luister & 87 & 82 & 169 \\
Ondersteuning & 66 & 51 & 117 \\
Rigtinggewing & 66 & \multicolumn{2}{|l}{} \\
\hline
\end{tabular}


Tabel 5 gee 'n uiteensetting van die belangrikste verwagtings wat die deelnemers van 'n mentorverhouding koester. Uit bostaande tabel is die belangrikste verwagtings volgens die deelnemers ondersteuning $(\mathrm{f}=169)$ gevolg deur rigtinggewing $(\mathrm{f}=117)$. Die oorblywende drie verwagtings het ook in 'n redelik hoë mate by die deelnemers gefigureer. Ander eienskappe wat uit die data na vore gekom het, maar waarvan die frekwensie laag was, is vriendelikheid, geduld, getrouheid, hulpvaardigheid, liefde, nederigheid, regverdigheid en om 'n rolmodel te wees.

In die lig van voorgenoemde behoeftes aan 'n mentor by die seun in sy oorgangsfase, is bevind dat hy sekere verwagtings van die mentor en die mentorverhouding koester.

\section{Gevolgtrekking}

Die seun in sy laat-middelkinderjare word daagliks deur veranderings gekonfronteer - deur uitdagings wat hy moet hanteer. Talle van hierdie uitdagings is dinge wat buite sy beheer lê, soos die bereiking van puberteit of die hantering van 'n egskeiding. Nog 'n verandering wat die seun moet leer hanteer, hou verband met verhoudings. Hierdie verhoudings sluit nie net verhoudings met die portuurgroep of met die teenoorgestelde geslag in nie, maar baie spesifiek ook met die biologiese pa.

Uit die voorafgaande bevindings is tot die volgende gevolgtrekkings gekom:

- Seuns afkomstig van die platteland ervaar hulle biologiese pa's wat by die gesin woon - meer aktief in hulle lewens as wat die literatuur aandui.

- Seuns op 12-jarige ouderdom ervaar hulle biologiese pa's, of hy by hulle woon of nie, die minste betrokke in hulle lewens, vergeleke met seuns van 13 en 14 jaar onderskeidelik.

- Die derde seun in die gesin volgens die gesinsrangorde het die grootste behoefte aan 'n mentor en die tweede seun die minste.

- Seuns is op soek na spesifieke eienskappe in 'n mentorverhouding. Die grootste behoefte ten opsigte van so 'n verhouding is aan ondersteuning en rigtinggewing.

- Seuns verlang 'n aktiewe mentorverhouding van 'n manspersoon waartydens die mentor aktief deel sal word van die lewe van die seun deur aktiwiteite saam met die seun te doen. Die seun toon 
'n behoefte dat die mentor hom moet beskerm, na hom moet luister en hom sal help met rigting in sy lewensverloop. Die grootste behoefte by seuns in albei geografiese streke is dat die mentor hulle moet ondersteun. Ander eienskappe wat 'n laer frekwensie toon, maar wat na vore gekom het, is vriendelikheid, geduld, getrouheid, hulpvaardigheid, liefde, nederigheid, regverdigheid en dat die mentor vir hulle 'n rolmodel moet wees.

\section{Aanbevelings}

Fokuspunte wat uit hierdie studie na vore kom, waaraan in verdere ondersoeke aandag geskenk kan word, is:

- die persoonlikhede en belewings van die verskillende gesinslede volgens gesinsrangorde;

- die seun in sy laat-middelkinderjare se belewing van 'n mentor, en die invloed van 'n mentor op die seun in sy laat-middelkinderjare asook op die adolessente seun.

\section{Samevatting}

In hierdie artikel is gefokus op die invloed wat die biologiese pa op die seun in sy laat-middelkinderjare het. Daar is egter 'n onderskeid getref tussen die biologiese pa wat by die gesin woon en die geskeide biologiese pa wat nie meer by die gesin woon nie. Uit die resultate is bevind dat die gesinsrangorde 'n rol speel by die seun se belewenis van die betrokkenheid van die biologiese pa.

Seuns in die oorgangsfase van die middelkinderjare na adolessensie het 'n behoefte aan 'n mentor - iemand na wie hulle kan opsien en wie se voorbeeld hulle kan nastreef; iemand wat hulle persoonlik ken en in hulle glo, hulle verstaan en die beste in hulle na vore bring. Seuns koester spesifieke verwagtings van 'n mentorverhouding. 


\section{Geraadpleegde bronne}

BABBIE, E. 2004. The practice of social research. 10th ed. Belmont: Wadsworth.

BARKER, R.L. 2003. The social work dictionary. 5th ed. Washington: National Association of Social Workers (NASW).

BERNARDES, J. 1997. Family studies: an introduction. London: Routledge.

BUHRMESTER, D. \& FURMAN, W. 1990. Perceptions of sibling relationships during middle childhood and adolescence. Child development, 61(5):13791398. Available: Google Scholar. Date of access: 23 May 2007.

COLE, M. \& COLE, S.R. 2001. The development of children. 4th ed. New York: Worth.

DELPORT, C.S.L. 2005. Quantitative data-collection methods. (In De Vos, A.S., Strydom, H., Fouché, C.B. \& Delport, C.S.L., eds. Research at grass roots: for the social sciences and human service professions. 3rd ed. Pretoria: Van Schaik. p. 159-191.)

EDWARDS, D. 1998. Motivering en emosie. (In Louw, D.A. \& Edwards, D.J.A., reds. Sielkunde: 'n inleiding vir studente in Suider-Afrika. $2 \mathrm{e} d r$. Johannesburg: Heinemann. p. 399-450.)

ELDREDGE, J. 2001. Wild at heart: discovering the secret of a man's soul. Nashville: Thomas Nelson.

ELDREDGE, J. 2006. The way of the wild heart: a map of the masculine journey. Nashville: Thomas Nelson.

ENCARTA DICTIONARY. 2006. (In Microsoft® Encarta ${ }^{\circledR}$ 2006.) [CD].

ERICKSON, B.M. 1996. Men's unresolved father hunger: intervention and primary prevention. Journal of family psychotherapy, 7(4):37-62.

FARRAR, S. 2006. Mentoring boys: what every son wants and needs from his father. Vereeniging: Christelike Uitgewersmaatskappy.

FOUCHÉ, C.B. \& DELPORT, C.S.L. 2005. Introduction to the research process. (In De Vos, A.S., Strydom, H., Fouché, C.B. \& Delport, C.S.L., eds. Research at grass roots: for the social sciences and human service professions. 3rd ed. Pretoria: Van Schaik. p. 71-85.)

FREEKS, F.E. 2004. Die rol van die ontbrekende vaderfiguur in die SuidAfrikaanse konteks: 'n prakties-teologiese studie. Potchefstroom: PU vir CHO. (M.A.-verhandeling.)

GURIAN, M. 1998. A fine young man: what parents, mentors and educators can do to shape adolescent boys into exceptional men. New York: Penguin Putnam.

HAVENGA, A.S. 2002. Maatskaplike intervensie in die instandhouding van die vader-kindverhouding na egskeiding. Potchefstroom: PU vir CHO. (M.A.verhandeling.)

HENDRICKS, H. \& HENDRICKS, W. 1995. As iron sharpens iron: building character in a mentoring relationship. Chicago: Moody Press.

JANSEN VAN RENSBURG, B.E.J. 2004. Riglyn aan Gestaltspelterapeute vir die hantering van egskeidingsverlies in die middelkinderjare. Pretoria: UNISA. (M.A.-verhandeling.)

KOTZE, J. 2004. Graad sewe-leerders van die Wolmer-gemeenskap se persepsies oor hulle toekomsverwagtings. Pretoria: Universiteit van Pretoria. (M.A.-verhandeling.)

LABUSCHAGNE, F.J. \& EKSTEEN, L.C. 1993. Verklarende Afrikaanse Woordeboek. 8e dr. Pretoria: Van Schaik. 
LARSON, R. 2006. Positive youth development, wilfulness adolescents, and mentoring. Journal of community psychology, 34(6):677-689.

LOUW, D.A., VAN EDE, D.M. \& FERNS, I. 1998. Die middelkinderjare. (In Louw, D.A., Van Ede, D.M. \& Louw, A.D., reds. Menslike ontwikkeling. 3e dr. Kaapstad: Kagiso Tersiêr. p. 325-383.)

NDABAZANDILE, S. 2006. South Africa needs real mentors. Saturday star: 14, 21 Jan.

NEUMAN, W.L. 2003. Social research methods: qualitative and quantitative approaches. 5th ed. Boston: Pearson Education.

O'CONNOR, T.G., DUNN, J., JENKINS, J.M. \& RASBASH, J. 2006. Predictors of between-family and within-family variation in parent-child relationships. Journal of child psychology and psychiatry, 47(5):498-510. Available: EBSCOhost. Date of access: 24 May 2007.

ODENDAAL, F.F. \& GOUWS, R.H. 2005. HAT: Verklarende Handwoordeboek van die Afrikaanse Taal. Kaapstad: Perskor.

PAPALIA, D.E., OLDS, S.W. \& FELDMAN, R.D. 2006. A child's world: infancy through adolescence. 10th ed. New York: McGraw-Hill.

POSEL, D. \& DEVEY, R. 2006. The demographics of fathers in South Africa: an analysis of survey data, 1993-2002. (In Richter, L. \& Morrell, R., eds. Baba: men and fatherhood in South Africa. Cape Town: HSRC. p. 38-52.)

PRUITT, D.B. 1999. Your adolescent: emotional and cognitive development from early adolescence through the teen years. New York: HarperCollins.

RATHUS, S.A. 2005. Psychology: concepts \& connections. 9th ed. Toronto: Wadsworth.

SANDERS, R. 2004. Sibling relationships: theory and issues for practice. New York: Palgrave MacMillan.

SOUTH AFRICA. 2004. Gaffney's local government in South Africa 2004 2006: official yearbook Est. 1909. Pretoria: Government Printer.

STRYDOM, H. 2005. Sampling and sampling methods. (In De Vos, A.S., Strydom, H., Fouché, C.B. \& Delport, C.S.L., eds. Research at grass roots: for the social sciences and human service professions. 3rd ed. Pretoria: Van Schaik. p. 192-204.)

WARREN, D.H. 1998. The fatherbook: a document for therapeutic work with father-absent early adolescent boys. Child and adolescent social work journal, 15(2):101-115.

ZASTROW, C.H. \& KIRST-ASHMAN, K.K. 2004. Understanding human behavior and the social environment. 6th ed. Belmont: Brooks/Cole.

\section{Kernbegrippe:}

gesinsrangorde

mentor

oorgangsfase: kind na adolessent

pa-seunverhouding

seuns: laat-middelkinderjare 


\section{Key concepts:}

boys: late middle childhood

family hierarchy

father-son relationship

mentor

transition phase:child to adolescent 
